\title{
Hybrid Identities/Hybrid Music: The Political Aesthetics of Arab Youth Musical Performances in Diaspora
}

\author{
Rowa Mohamed Nabil ${ }^{1}$
}

\begin{abstract}
This paper analyzes the interaction between the musical productions and the cultural identity of young Arab musicians in Western diaspora. The theme of 'hybridity' tackles questions of cultural identity and identity politics, particularly when the musical performances in diaspora and imposed self-exile voice political struggles in the homeland, and manifest the musicians' national consciousness. Highlighting political aesthetics and ideologies of transnationalism, the present research examines the musical performances of two Arab bands in Western diaspora. The first is '47Soul', a London-based band of Palestinian origins that fuses the music folklore of the Levant, with electronic sonic systems, in musical hybrids negotiating the Palestinian musical identity. The second is 'Nas Jota,' a Sudanese music group and production platform based in the United States of America. Nas Jota produces Arabic hip-hop performances, mixed with African reggae, employing heteroglossic linguistic variations, to articulate political protest against the autocracy of Sudan's former regime. The paper aims to illustrate the transcultural exchange of musical and lyrical features reflective of the musical hybrids and hybrid identities emerging in light of the diasporic and exilic experiences. The paper places the musical hybrids in the cultural and political contexts of their composition and reception. Offering an interdisciplinary approach, the paper argues that the hybrid identities of these young Arab musicians is represented in the hybridity of the musical fusions. In addition, the engagement of the musical hybrids with national popular struggles in the homeland sheds light on national identity ties.
\end{abstract}

\footnotetext{
${ }^{1}$ Rowa Nabil, Assistant Lecturer, the Department of English Language and Literature, Cairo University.
}

مجلة علوم وفنون الموسيقى - كلية التربية الموسيقية - المجلل ج؟ - عدد خاص "الموسيقى وهوية الشعوب" - أغسطس اr.rه. 
Keywords: musical hybrids, musical fusion, artivism, Sudanese rap, Shamstep, political aesthetics, identity politics.

\section{Musical Hybrids: Space for Restoration, Negotiation, \& Resistance}

Arab youth have been taking a stand against the troublesome conditions of their respective communities, varying from social marginalization to state corruption. During the last decade, they have engaged with sociopolitical issues symptomatic of their realities by means of artistic activism. Their artivism -artistic activism- is manifested in committed musical productions that reflect, not just their political grievances and aspirations, but also their cultural identity and national consciousness. ${ }^{2}$ Despite being constantly pushed to the margin by the stigma of being disruptive social actors, prone to civil deviance, young Arabs have manifested their power in altering the dynamics of politics in the region, by "creating and disseminating messages and images to define themselves on a public stage." 3 Opting for non-violent artistic activism in the face of oppression, young Arab singers and musicians embody the faith and doctrine that Tawfiq al-Hakim has hoped the young generation would institute; "noble ends are reached by noble means!"4 Although there is a long legacy of musical performances and compositions employed as tools of artistic activism in the Arab world, the contribution of young Arab artists in diaspora and self-exile poses questions pertaining to cultural and identity politics.

The quintessential intercultural exchange between the 'local' and 'global' shapes the identities and musical performances of young Arab musicians in Western communities. The 'glocalized' exchange of cultural features and musical practices produces transcultural musical hybrids that

\footnotetext{
${ }^{2}$ For further discussion on Arab artivism, and the engagement of young Arab singers and musicians in artistic activism during waves of popular political contention between 2010 and 2013, see Rowa Nabil, "The Young Sing Back" (MA thesis, Cairo University, 2020).

${ }^{3}$ Linda Herrera and Asef Bayat, Being Young and Muslim: New Cultural Politics in The Global South and North (New York: Oxford University Press, 2010), 363.

${ }^{4}$ Tawfiq Al-Hakim, The Revolt of the Young: Essays by Tawfiq al-Hakim, trans. Mona Radwan (New York: Syracuse University Press, 2015), 38.
}

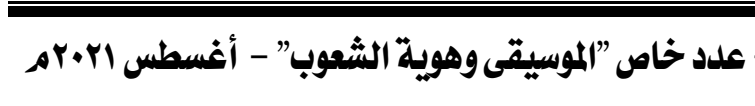


do not fully comply with either of the initial originary culture, or the globalized practices. In the context of this research, 'hybridity' is viewed as the process of creating "new transcultural forms" as a result of the interactions between two existing cultural forms. ${ }^{5}$ The newness of the hybridized forms, practices, and identities is stressed in contrast to the collaged remixing, or the recitation of existing forms. The transculturality of the hybrid stems from the cross-cultural exchange, during which the existing cultural positionalities contribute- not necessarily equally- in the construction of a new hybridized space. Hybridity is, hence, a 'third space' where the two prior positions are simulated, reproduced, and re-presented to give rise to new identifications and representations. ${ }^{6}$ It is the 'in-between space' where tradition and indigeneity provide a partial form of identification in the ongoing process of cultural negotiation during moments of transformation. ${ }^{7}$ Thus, the hybrid is a space for negotiation between the heterogenous particularities of the local, and the universality of the global. The heterogeneity of the cultural and musical identity is not absorbed or neutralized, as to make room for the adoption and assimilation of globalized features. Instead, cultural hybridity entails that tradition is restored and reconfigured to innovate original significance and meanings, while the present is interrupted to actively mediate self-identification and self-performance. ${ }^{8}$

In the context of this study, the dynamics of transcultural interaction and negotiation that guide musical hybridity occur in light of forced displacement. As a result, cultural politics as well as contentious politics weigh in the construction of the hybrid identities and musical hybrids. The experience of forced displacement imposed by an oppressor, with limited or no hope of return, has shaped the cultural and musical identities of various young Arab artists. As a direct result of occurring in line with such an experience, the restoration and incorporation of indigenous musical

\footnotetext{
${ }^{5}$ Bill Ashcroft, Gareth Griffiths, and Helen Tiffin, Post-Colonial Studies: The Key Concepts (New York: Routledge, 2007), 108.

${ }^{6}$ Homi Bhabha, "The Third Space," in Identity: Community, Culture, and Difference, ed. Jonathan Rutherford (London: Lawrence and Wishart, 1990), 210.

${ }^{7}$ Homi Bhabha, The Location of Culture (New York: Routledge Classics, 2004), 3.

8 lbid, 10.
}

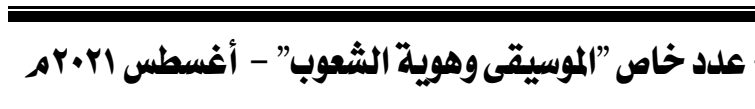


forms, local linguistic practices, and sociocultural folk traditions acquire then propagate distinctive signification and meaning, compared to their original significance in the existing originary culture. These processes of restoration and negotiation are exceptionally vital for young Arab musicians born in diaspora to refugee parents with no right to return, and for artists born in the homeland but had to resort to self-exile to flee political persecution orchestrated by an authoritarian regime. The diasporic and exilic presence conditions and guides the production of musical hybrids, as well as the construction of the hybrid identity. In the process of constructing new and original musical hybrids, the hybrid interrupts the present dispossession to bring to the forefront heterogenous elements of the homeland. Hence, the reconfiguration of the heterogenous particularity of the musical heritage and cultural tradition is subversive of the imposed detachment and alienation. The performance of hybrid music is a performance of an identity, while both performances tell a story of the self, describing "the social in the individual and the individual in the social."9

Besides being expressive of the processual defiant self-identification, the political aesthetics of these musical hybrids are instrumental in political resistance and activism. They voice political protest against the oppressive power bloc responsible for the inflicted isolation and dislocation. This power bloc can be a military occupation imposing mass dispossession as in the performances of the Palestinian band 47Soul; or an authoritarian regime operating on basis of political persecution and oppression as in the case of the Sudanese music group Nas Jota. Both 47Soul and Nas Jota create musical hybrids that assert national identity ties, accentuate the artists' national consciousness, and bridge their commitment to the national struggles of their brethren in the homeland. The musical hybrids discussed in this paper are distinctive fusions of linguistic and musical structures transpiring from what Weiss coins as "intentional hybrids," which are the products of conscious blends and transcultural fusions. ${ }^{10}$ The musical

\footnotetext{
${ }^{9}$ Simon Frith, "Music and Identity," in Questions of Cultural Identity, ed. Stuart Hall and Paul Du Gay (London: Sage Publications, 2003), 109.

${ }^{10}$ Sarah Weiss, "Permeable Boundaries: Hybridity, Music, and the Reception of Robert Wilson's "I La Galigo," Ethnomusicology 52, no. 2 (Spring/Summer 2008): 206.
}

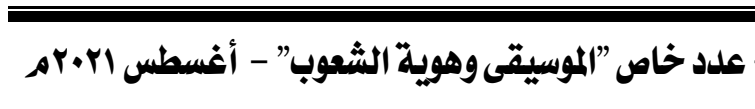


hybrids of these two bands are, thus, the self-generated space in which the restoration of the local folk repository, and its negotiation within the global musical topographies take place to produce original transcultural musical hybrids instrumental in political resistance.

\section{Soul: The Shamstep and Electro-Dabke}

Among the particular features associated with the Palestinian identity is the collective history of forced displacement. Since 2013, and the inception of their collective music career, the four young Palestinian musicians behind 47Soul have expressed their defiance against the restrictions on mobility enacted in the region since the Sykes-Picot Agreement. For 47Soul, forming the band against dispersion is a political statement they fully intend to communicate, ${ }^{11}$ while the name of the band is a statement against restricted border-crossing. ${ }^{12}$ Likewise, the coming together of the four young Palestinian musicians from different parts of the world to create 47Soul represents a unique form of defiant unity. Tareq Abu Kwaik, who goes by the nom de guerre El Far3i, is the vocalist, multiinstrumentalist, and percussionist in 47Soul. Abu Kwaik is known for his jabali Bedouin vocalist style, as well as his politically-charged rap. Hamza Arnaout, known as El-Jehaz, is the guitarist and music producer, associated with the rock music scene in Jordan. Both Abu Kwaik and Arnaout are Palestinian Jordanians, who grew up in Amman. The vocalist and keyboardist in 47Soul is Ramzy Suliman, who goes by Z-the-People. He is a Palestinian American, born and raised in Washington, D.C. to Palestinian parents. Suliman merges the root music of the American soul and gospel, with the mijwiz using the analogue synthesizer. Walaa Sbeit, the vocalist and percussionist, is among the Palestinian population residing inside the Occupied Territories, commonly referred to as 'Arab Israel,' and Arab 48. Residing in the occupied city of Haifa, Sbeit identifies himself as being an "internal refugee" in his homeland. ${ }^{13}$ The restriction on mobility is a key challenge the young musicians had to face, as Abu Kwaik explains, "we as

${ }^{11}$ Walaa Sbeit, in discussion with the author, June 13, 2014, Alexandria.

12 47Soul, "Shamstepping Across Borders," SceneNoise, June 3, 2018.

${ }^{13}$ 47Soul, "Palestinian supergroup 47Soul stay true to their roots," The National, Aug. 17, 2016.

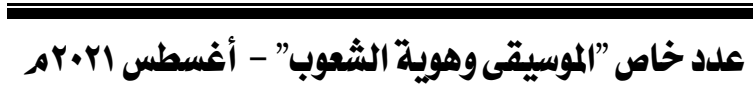


a band come from places we cannot all be in. Walaa is Palestinian and holding an Israeli passport...Me and Hamza have Jordanian passports. Ramzy is Palestinian but he has an American passport. I won't be allowed to go to Walaa's house, ever." 14 Nevertheless, the band members have persisted to bring their music live to the stage, and on online platforms.

Furthermore, members of 47Soul recognize that it is the responsibility of every artist to understand the dynamics of identity politics in such a globalized age. The band members assert that their music takes a step closer to the homeland, before branching out towards cultural diversity. ${ }^{15}$ That is why the band's musical hybrids embark from the folkloric dabke as a point of departure. The sonic experience of Palestinian national music is displayed in the indigenous dabke rhythms with the sound of the mijwiz being the predominant accompaniment in the performance. ${ }^{16}$ Consequently, mixing the fusions and the modernized global alternations without compromising the particularity of the musical folklore outlines the musical identity of 47Soul. The young musicians come to define their musical hybrid as electro-dabke, a music style they have created and launched under the name 'Shamstep'. Shamstep depends on the consistent and distinguishable sonic presence of the traditional mijwiz played on the synthesizer. The synth mijwiz is accompanied by a live set of percussions, as the band blends the spoken English with the Shami/Levantine Arabic dialect. The band describes their version of electro-dabke as a fusion of elements from the musical heritage of the Levant, such as the traditional qataqofti and malfoof rhythmic schemes with corresponding folk rhythms in the Jamaican dancehall, and traditional structures of the Latin reggaetón, along with the more contemporary Afro-American hip-hop, and the European rock. ${ }^{17}$

14 Tareq Abu Kwaik, "Traditional Arabic Street Music Gets Electronic," BBC News, March 21, 2015.

${ }^{15}$ 47Soul, "Shamstepping Across Borders."

${ }^{16}$ David McDonald, My Voice Is My Weapon: Music, Nationalism, and the Poetics of Palestinian Resistance (London: Duke University Press, 2013), 115.

17 47Soul, “Q\&A Live from YouTube Space Dubai," interview with Azza Za'rour, July 11, 2019.

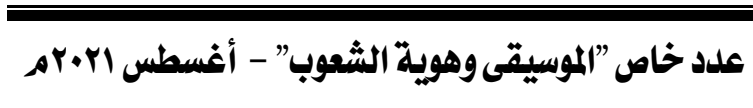


Moreover, 47Soul's musical and cultural identity is signified in the band's name, which refers to the soul of 1947 Palestine and Bilad al-Sham (the Levant) before the Nakba and the exodus in 1948. 47Soul aims to restore the soul of rural Palestine, and the folk musical heritage of Bilad alSham. ${ }^{18}$ Such rural fallahi (peasantry) folk heritage constructs the indigeneity of the national narrative of precolonial Palestine. ${ }^{19}$ There have been relentless hegemonic projects to send the Palestinian precolonial rural heritage to omission, in order to advertise the Zionist maxim of 'a land without a people for a people without a land.' The absence of a cultural tradition prior to the Israeli occupation equates the absence of citizenry and civilization. There are, also, Zionist claims that Palestinians do not have a particular national identity beyond the regional Arab identity, and, hence, "can easily assimilate anywhere in the Arab world." ${ }^{20}$ In resistance, Palestinian artistic and musical productions preserve and disseminate the rural heritage, and the indigenous representations of the precolonial agriculturalist community in their productions. In their "Intro to Shamstep," released in 2015, 47Soul introduces their musical hybrid genre illustrating a response to the question: "what is the soul of the 47?" to which the answer is "Sham put the soul in the 47 ...back to the peasant to the fallahin-born." ${ }^{21}$ The band even features the figure of the peasant and the dabke dancer in the visuals accompanying the performances. The fallah (peasant) is the central signifier of the Palestinian national past, and the "symbolic representative of the cultural and historical continuity of the Palestinian people" before the Nakba of $1948 .{ }^{22}$ The identification of 47Soul as diasporic young musicians with the precolonial national identity and cultural archive is subversive of omission and public amnesia. The restoration, negotiation, and incorporation of the precolonial folk music of the rural peasantry are politically strategic processes in the PalestinianIsraeli conflict, since the sustained assertion of a shared precolonial

\footnotetext{
${ }^{18}$ 47Soul, "Shamstepping Across Borders"; and 47Soul; "Reviving the Shami Folk Heritage," France 24 Arabic, May 6, 2016.

19 Juliane Hammer, Palestinians Born in Exile: Diaspora and the Search for a Homeland (Cairo: American University Press, 2005), 32-33.

20 Ted Swedenburg, Memories of Revolt: The 1936-1939 Rebellion and the Palestinian National Past (Minneapolis: University of Minnesota Press, 1995), 6.

21 47Soul, "Intro to Shamstep," track 1 on Shamstep, Independent Records Ltd, 2015.

${ }^{22}$ Swedenburg, Memories of Revolt, 22.
} 
national past legitimizes the struggle for the right to return. The preservation of the indigenous practices such as the dabke, and the indigenous instruments such as mijwiz is the preservation of the nation, and resistance to systematic erasure of its history, heritage, and culture. ${ }^{23}$

In addition to the sonic fusions of electro-dabke with African and Western sonic structures, the blend in the linguistic features reflects another layer of the political aesthetics of 47Soul's musical hybrids. This is demonstrated in how the band's musical performances emphasize solidarity and inclusion. The signature performance "Every Land" embodies their musical fusion, through which their politically-charged lyrics voice resistance against apartheid and exclusion. Deconstructing the Zionist supremacist ideology and segregationist practices, 47Soul voices equality, solidarity, and inclusion:

Every land is a holy land.

Every people is the promised people.

From Africa to Palestine, the sunlight will shine,

Oh, my comrade! Pick up, live up, your self and mind!

We say to Babylon we are here despite the oppression,

We'll be back, Abdel-Nasser, and Mandela, Nelson. ${ }^{24}$

The fusion of the African reggae beats and Jamaican rhythms with Shami folk music in this hybrid performance highlights the solidarity between the Arab and the African regions. The transnational solidarity is further complemented by the lyrical reference to two former political leaders: Gamal Abdel-Nasser, and Nelson Mandela. Incorporating the figure of Egyptian President Abdel-Nasser recalls the pan-Arab camaraderie and nationhood; whereas the figure of Mandela recalls a long legacy of civil right activism against apartheid and racial divisions in South Africa. Bringing together traditional musical elements from both cultures, as well as political figures representative of both regional identities, 47Soul

\footnotetext{
${ }^{23}$ McDonald, My Voice Is My Weapon, 22; 114-115.

24 47Soul, "Every Land," track 5 on Shamstep, Independent Records Ltd, 2015. (This verse is composed and performed in the English language).
}

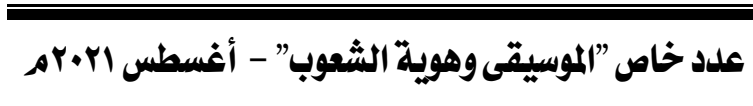


restores and negotiates transnational identity ties to the Arab and African cultures, while asserting their musical identity as a hybrid of traditional roots. The refrain is repeated while oscillating between the English language and the Levantine variety of Arabic, to convey the "screams" of the oppressed, and the voices in "refugee camps" around the world: "min afrikya la falasteen eid wahda shabkeen" [from Africa to Palestine, hand in hand] ${ }^{25}$ Although the hybridity between dabke and electronic music is not new, 47Soul has turned it into a consistent music style and musical identity, through their production of original musical performances- a statement not meant to undermine the impact of folk revival on enriching the Palestinian music tradition.

It is noteworthy to add that the question of 'cultural authenticity' pertaining to political aesthetics of Palestinian hybrid performances cannot be decontextualized, or removed from the sociopolitical realities of production and consumption. This is displayed in how young Palestinian artists inside Palestine may not perceive cultural authenticity and the reproduction of national musical heritage as commitment to the Palestinian struggle. ${ }^{26}$ Besides, Palestinian artists inside Palestine are engaged in cultural and artistic activism against the hegemonic whitewashing of the atrocities committed by the Zionist occupation. Such hegemonic agenda is channeled through musical projects since the Gaza-Jericho accord in $1994 .{ }^{27}$ Yet, for young Palestinian musicians in diaspora, such as 47Soul, producing musical hybrids that bring to the forefront the indigenous features of the folk tradition is reflective of their particular diasporic experience and their idiosyncratic hybrid identity in diaspora. That is to say, the struggle against violence and detention inside the colonized homeland gives rise to musical identity that differ from the musical identity shaped in the backdrop of diasporic experiences. As a result, the globalized stylistic innovations in the musical hybrids of young Palestinians in diaspora are consciously and intentionally deployed, and "cannot be

25 47Soul, "Every Land" (transliterated and translated to English by the author).

${ }^{26}$ Sunaina Maira, Jil Oslo: Palestinian Hip Hop, Youth Culture, and the Youth Movement (Washington: Tadween Publishing, 2013), 77-81.

${ }^{27}$ Nili Belkind, "Music in Conflict: Palestine, Israel, and the Politics of Aesthetic Production" (PhD diss., Columbia University, 2014), 17-20.

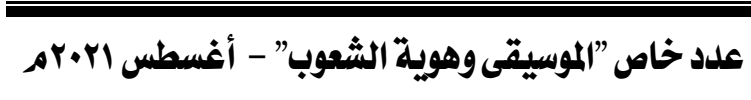


understood in simple terms that resemble processes of musical modernization and Westernization in other countries." 28 The restoration and negotiation of the precolonial roots, and claiming the homeland through musical hybrids subverts the Zionist project that promotes the erosion of the distinctive features of the indigenous Palestinian identity and culture.

\section{Nas Jota: Sudanese Rap of Protest}

Nas Jota's musical hybrids reveal their national consciousness, and close attachments to their Sudanese national identity. Nas Jota is a music group and production platform that engages with sociopolitical issues relevant to the Sudanese reality through Arabic rap. Based in the United States of America, Ehab Abasaeed, founder of Nas Jota, asserts that Nas Jota produces committed musical performances that raise awareness, deliver a positive message, and pronounce the injustices against ordinary citizens in the homeland. ${ }^{29}$ Nas Jota creates and fosters fusions of Arabic hip-hop that highlight and disseminate the national aspirations of the Sudanese citizens. Musicians associated with Nas Jota use the aesthetics in their musical hybrids as political tools of activism against political repression, state corruption, and the deteriorating living conditions in Sudan.

In 2010, prior to the then-impending presidential elections, Sudan's popular movement Girifna (We're Fed Up!) organized cultural campaigns to raise awareness regarding voting registration. Girifna is an unarmed youth-driven grassroot movement shaped in 2009, against al-Bashir's Islamist-military autocracy. Through launching peaceful civil protest and cultural activities, Girifna activists and artists mobilized for political reform in Sudan. ${ }^{30}$ Concurrently, in 2010, Nas Jota released a musical performance "ehmiha b-sotak" (protect it with your vote/voice), in order to

${ }^{28}$ Chuen-Fung Wong, "Conflicts, Occupation, and Music-Making in Palestine," Macalester International 23 (2009): 271.

${ }^{29}$ Ehab Abasaeed, in discussion with the author, August 24, 2020, Cairo.

${ }^{30}$ Gada Kadoda and Sondra Hale, "Contemporary Youth Movements and the Role of Social Media in Sudan," Canadian Journal of African 49, no. 1 (2015): 222. 
encourage citizen participation in the voting process, and the democratic transition of power. It is a hopeful and optimistic invitation of the "invincible" people of Sudan to participate in determining the future of their homeland, by overcoming their silence to protect their nation. ${ }^{31}$ The hybrid musical performance blends hip-hop, with electronic dubstep, and Algerian Rai. The performance features a collaboration between Nas Jota and artists in the homeland and abroad, including local rapper Langa, Algerian Rai singer Cheb Yassine, and the African-American rapper Messiah Ramkissoon. The collaboration between American, Arab, and Sudanese artists inside the homeland and abroad was directed towards mobilizing Sudanese citizens around the world to take part in the elections. However, following the release of "ehmiha b-sotak," Nas Jota's rapper elSadiq Sedeeq was kidnapped, detained, and beaten by the regime's security apparatus that accused him of supporting foreign agendas through the musical performance. ${ }^{32}$ While many artists were forced out of the country, Sedeeq is the only Nas Jota member who remained inside Sudan, and, consequently, became a target of the regime's extensive persecution whenever the band released a new performance online.

Nas Jota's musical hybrids signify more than just their loyal attachment to their homeland. Nas Jota focuses on creating music collaborations with diasporic artists of diverse social and ethnic identities to echo a particularly significant issue influencing Sudan's national identity: civil fragmentation. For over 30 years, al-Bashir's regime has systematically fueled sectarianism and civil divisions in Sudan. The Islamist-military autocracy pushed forward an Islamist agenda that excludes non-Islamists from governmental positions, advertising a discourse that frames this exclusion as reform and empowerment. ${ }^{33}$ In addition to imposing social and political isolation on Christian citizens, the regime continuously failed to resolve the ongoing armed conflict in Darfur, which was instigated by the persecution and oppression of non-Arab ethnic groups. The socio-national fiber of the Sudanese society became

\footnotetext{
${ }^{31}$ Nas Jota, "b-Sotak" [with Your Voice/Vote], Nas Jota Records, 2010.

${ }^{32}$ Ehab Abasaeed, in discussion with the author, August 24, 2020, Cairo.

${ }^{33}$ Kadoda and Hale, "Contemporary Youth Movements," 217.
} 
exceptionally compromised with the secession of the predominatelyChristian region of South Sudan. Thus, the sectarian divisions and social fragmentation have been collective national grievances affecting the Sudanese national identity. In response, Nas Jota produces musical hybrids that articulate the mass dissidence against the oppressive regime that persecuted the artists into self-exile, and fueled the civil strife in Sudan. Their musical hybrids, also, subvert the physical alienation in diaspora by engaging with issues of national concern to the brethren in the homeland. Nas Jota artists align their physical alienation in diaspora and self-exile with the political and social marginalization of the people in the homeland.

Moreover, forming artistic coalitions and musical collaborations in diaspora is a statement of national unity and camaraderie, against the state and its segregationist policies. Such collaborations indicate national and transnational commitments and solidarities among dispossessed communities of Sudanese away from their homeland. Therefore, the political aesthetics in their hybrid musical performance stem from the subversion of the regime-bred fragmentation, by including diverse Sudanese voices to convey a unified national identity. This national identity is clearly illustrated in Nas Jota's signature performance "la lil diktatoreya" (No to Dictatorship), through which a multilingual fusion of standardized Arabic and Sudanese dialects communicates the heterogenous features of Nas Jota's musical hybrid. In this hybrid performance, Nas Jota employs heteroglossia through the lyrical fusion of multiple local varieties of the Arabic language from different geographical regions of Sudan to signify a unified socio-national fiber. The political protest in the lyrics interpenetrates a fusion of African reggae and hip-hop. Composed and released along with the eruption of Sudan's mass protests in 2011, the performance states the repudiation of decades of state corruption, social injustice, and Islamic fundamentalist ideologies, as the repeated refrain states "la lil diktatoreya! la li hokoma seyadeya!" [No to dictatorship! No to the authoritarian government!]. ${ }^{34}$ The hybrid performance encompasses

${ }^{34}$ Nas Jota, "La lil Diktatoreya," Nas Jota Records, 2012 (transliterated and translated to English by the author). 
three Sudanese rappers from different geographical locations representing diverse ethnic identities. The Sudanese dialects are unified in their articulation of the citizens' popular demands. Ayman Youssef, who goes by the nom de guerre Ayman Mao, is a reggae musician and performer from Khartoum. He has resorted to self-exile in the United States of America after being persecuted and imprisoned for his music by al-Bashir's regime. Ayman Mao returned to Sudan for the first time in 2019 after spending 10 years in self-exile, where he lived and worked, believing he would never see the river Nile again in his life. ${ }^{35}$ El-Sadiq Sedeeq is a rapper who performs in the Sudanese vernacular commonly used in the northern region. Based in Washington D.C., Deng Mabur- who goes by the stage name Mista-D- is South Sudanese rapper, from the city of Bor. Like Ayman Mao, Mista-D arrived to Sudan after the ouster of al-Bashir, and after 14 years away from home. His contribution in "la lil diktatoreya" is an intriguing form of hybrid musical performance.

Being a Christian from South Sudan where English is the official language, the stylistic fusions in Mista-D's performance represent his multicultural identity. Mista-D's English rap verse, and his affiliation with African music structures do not represent the identity featured in diaspora. In fact, they are the authentic features reflecting his indigenous multicultural identity as South Sudanese. His hybrid identity actually appears as he switches to the Sudanese-Arabic dialect. For Mista-D, it is employing Arabic lyrics in the linguistic blend that marks his transnational hybrid identity. In "la lil diktatoreya" (No to Dictatorship), he engages in codeswitching, alternating between spoken English and the Sudanese vernacular:

Till when we'll be living like jobana [cowards]

Gowa hilitna [inside our neighborhood] like sojana [prisoners]

We never speak the truth cause lisanna [our tongue]

Marbot, ma fy amana [tied up, no honesty]

Till when we'll be living in dolomma [darkness]

${ }^{35}$ Ayman Mao, "The Voice of the Revolution in Sudan," BBC, May 15, 2019.

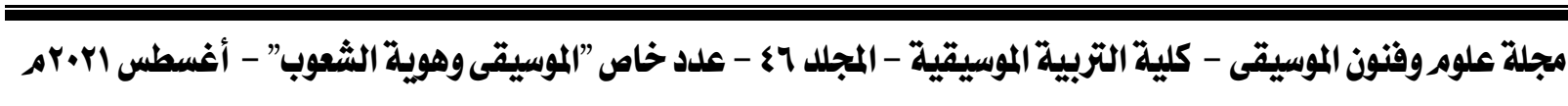


22 years $w$ ma gadrin netlamma [and we can't get together]. ${ }^{36}$

The juxtaposition of English and Sudanese variety of the Arabic language through codeswitching asserts Mista D's multicultural identity, and restores the national ties severed by religious sectarianism and social division in Sudan. The codeswitching and the heteroglossic blend of English, Standardized Arabic, and Sudanese vernaculars in Nas Jota's performance is a reinstatement of the unified Sudan, and articulation of solidarity against the state-induced civil fragmentation.

In 2019, and during the final wave of the Sudanese uprisings against al-Bashir's Islamist-military regime, members of Nas Jota and other dispossessed Sudanese artists and musicians returned to Sudan to participate in the protest activities and the popular movement. Nas Jota launched their first live performance inside Sudan in April 2019, during a sit-in on the street. After the ouster of al-Bashir, Nas Jota performed live on stage in Khartoum, on New Year's Eve. The concert was a charity event dedicated towards raising donations to rebuild the new Sudan, with the concert raising the slogan ha-nebniha (We'll Build It!).

\section{Conclusion: Performing the Hybrid Self}

Diasporic and exilic experiences have inevitable and irrevocable influences on the musical performances of the young Arab artists behind 47Soul and Nas Jota. Hybrid cultural identities are points of identification, determined by the active positioning in relation to the heterogenous particularities of the originary culture. Through hybridity, this originary position is constantly reproduced, re-presented, reconfigured, and reimagined anew. ${ }^{37}$ For 47 Soul, the heterogenous particularity is the multilayered sonic structure, whereas for Nas Jota, it is the multiethnic lyrical structure. For both bands, the points of identification and identity positioning that navigate the reconfiguration of the newly generated

\footnotetext{
${ }^{36}$ The italicized words are transliterated and translated to English by the author.

${ }^{37}$ Stuart Hall, "Cultural Identity and Diaspora," in Identity: Community, Culture, Difference, ed. Jonathan Rutherford (London: Lawrence \& Wishart, 1990), 226; 235.
}

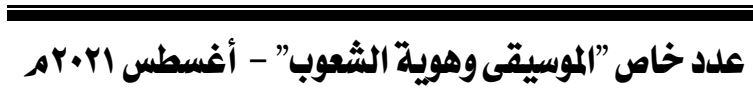


musical hybrids are political experiences. The musical hybrids produced by 47Soul and Nas Jota contribute to the global music scene of the worldbeat, while articulating commitment to the national struggles in their respective homelands. Both manifestations of hybrid identity and musical hybrids are imbedded in sociopolitical struggles and cultural politics. Hence, these musical hybrids cannot be viewed solely as musical compositions in their soundscapes divorced from the political experiences. The present research emphasizes the importance of placing the musical hybrids in the political and sociocultural contexts of their production, dissemination, and reception.

The sonic diversity, melodic fusions, and lyrical blends in the performances of 47Soul and Nas Jota give rise to intentional and conscious musical hybrids that mirror a hybrid identity. The hybridity characteristic of their performances does not entail that the heterogenous features of their cultural and musical identities have been neutralized or acculturated. In 47Soul's hybridized genre of Shamstep, the popular musical identity of the Levant is alive and vivid since the folkloric dabke and mijwiz are the focal points on which the musical hybrid is founded. Nas Jota's musical hybrid of Arabic rap is empowered by the linguistic localization, heteroglossia, and the thematic attachment of the performances to the national grievances during national political contention. As a result, the musical hybrids of the two bands do not sanction westernization or foreignization at the expense of eroding the traditional particularities. Moreover, dualities of localization/globalization and authenticity/modernity are not uniform or fixed since they go through a continuously dynamic flux of negotiation and appropriation. In the context of imposed dispossession and self-exile, such ongoing dynamic flux is conditioned by the battle against restrictions on mobility and regime repression. The intentionality of producing musical hybrids indicates that the forced estrangement does not preclude sociocultural engagement or national commitment. The appropriation of contemporary melodic and rhythmic trends within the folk musical heritage, and the incorporation of heteroglossic linguistic variations are 
strategically executed processes to produce musical hybrids that protest and subvert the physical alienation.

Despite their sonic, linguistic, and political variations, the musical hybrids of 47Soul and Nas Jota share two significant features of political aesthetics: the resistance against forced displacement, and the assertion of transnational camaraderie. 47Soul and Nas Jota pronounce transnational inclusion, through collaborations with other diasporic artists. The formation of the two music groups despite the imposed fragmentation is a political statement of defiant unity. Furthermore, the two bands manifest transnational camaraderie, and solidarity that crosses borders. Both 47Soul and Nas Jota subvert the imposed estrangement and alienation through musical hybrids and collaborations exhibiting a heightened sense of transnational connectedness. The political aesthetics and activist instrumentality are illustrated in reclaiming the homeland by reclaiming its musical heritage, and negotiating its folk elements in original multitextured performances, as in the hybrid performances by 47Soul. They are, also, manifested in reclaiming the local roots through linguistic tools and local vernacular dialects from native communities, negotiated in heteroglossic lyricism, as in Nas Jota's performances. The interpenetration of indigenous melodic structures in Westernized music forms loaded with folk idioms and local vernacular dialects is symbolically and politically strategic. In other words, the multilingualism and translanguaging in the lyrical component, and the transcultural fusions in the sonic component of these musical hybrids are not momentary displays of fortuitous remixing, or folk revivalism.

Cultural hybridity is essentially a process of identification that generates a previously unrecognizable third space where new representations and performances are negotiated ${ }^{38}$. This 'in-between' third space is neither produced by the passive extension of received ethnic or cultural tradition, nor by complete assimilation and acculturation. Rather, it is a terrain where active agency is exercised for the identification of

${ }^{38}$ Bhabha, "Third Space," 211.

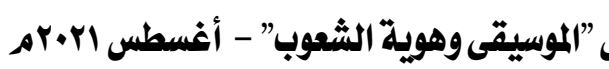


collective and individual selfhood. ${ }^{39}$ The present paper, hence, contends that musical hybrids of 47Soul and Nas Jota are spaces of negotiation, restoration, and resistance. They interrupt the dualities of authenticity and universality as the elements of the originary musical and cultural tradition are reproduced and transformed to give rise to alternative significance and meanings. Restoring and negotiating the indigenous dabke and mijwiz originally associated with Palestinian weddings and celebrations into musical hybrids that voice political resistance against restrictions on mobility transform the significance and meaning of the indigenous sonic experience itself. The dabke and mijwiz in 47Soul's musical hybrids acquire different significance distinct from their cultural meaning in the Palestinian folk heritage. The 'third-space' created by 47Soul's hybridized genre of Shamstep is where the precolonial musical heritage of the peasants and their celebrations is transformed into a tool of cultural and political resistance and self-affirmation against systematic cultural erasure by the Zionist hegemony. Furthermore, negotiating and incorporating the diverse local Sudanese dialects in hip-hop beats that articulate political protest and dissidence against the autocratic regime alter the linguistic significance of local varieties of the Arabic language. The multiethnic lyricism of Nas Jota's musical hybrids acquires a political significance of demonstrating national unity, subversive of the state-bred civil fragmentation. For Nas Jota, the 'third-space' produced by their hybridized Arabic rap is where the globalized hip-hop is reproduced as tool for political protest against national grievances in local communities voiced by native dialects. For young Arab musicians in diaspora and self-exile, the musical hybrid is a performance of the multi-layered and multi-tonal hybrid 'self.' The amalgamation of sonic and lyrical components from both the folk repository and global topographies is an exercise of identity construction and assertion of both the self and the nation.

\section{Acknowledgement}

${ }^{39}$ Bhabha, Location of Culture, 2-3.

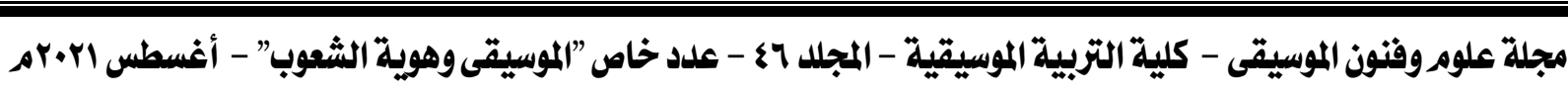


I would like to express my sincerest gratitude to my two anonymous peer reviewers, who took the time to read the paper critically, and send constructive input. Their revisions and feedback have significantly improved the clarity of the paper's argument. 
هويات هجينة/موسيقى هجينة: جماليات سياسية في عروض موسيقية للشباب

$$
\text { العربي في المهجر }
$$

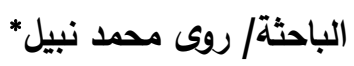

هذه الورقة البحثية تقدم تحليل للتفاعل بين الإنتاج الموسيقي و الهوية الثقافية للموسيقيين الثباب

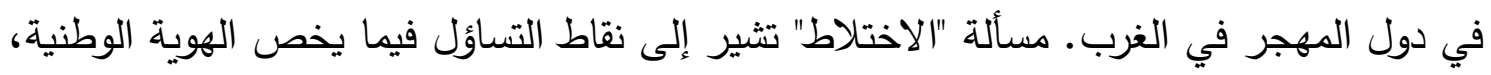

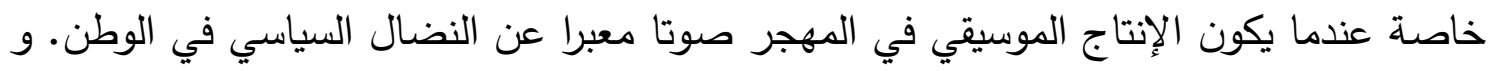

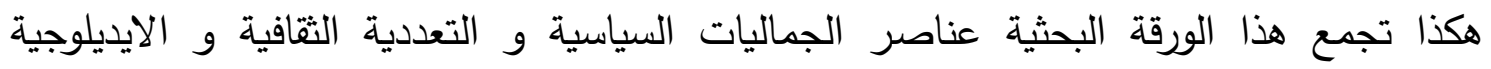
الوطنية في دراسة الإنتاج الموسيقي و الأغاني لاثثين من الفرق الموسيقية العربية في المهجر

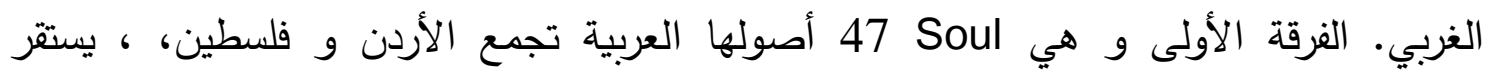

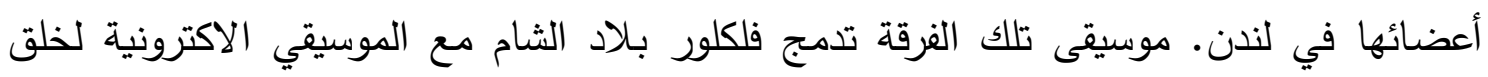

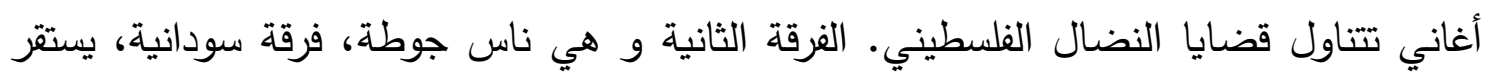

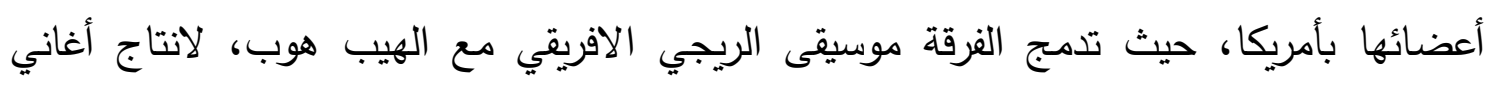

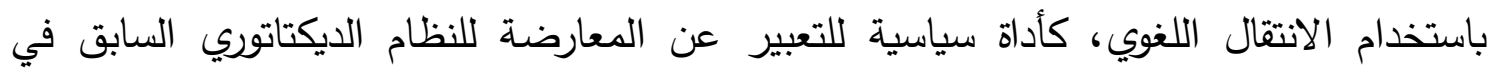
السودان. هذا البحث يسلط الضوء على التبادل بين الثقافات حيث تلتقي السمات التراثية التي تمثل

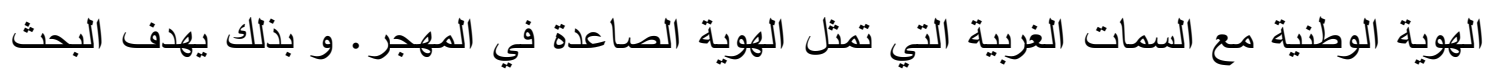

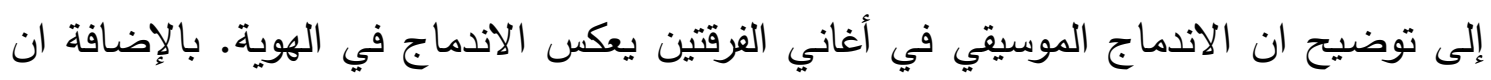

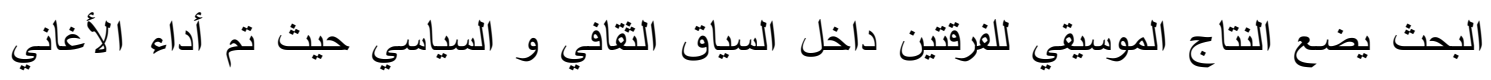
للجمهور و ذلك يؤكد دور ذلك النتاج الموسيقي في تمثيل النضال الثعبي في الوطن. يتبع البحث

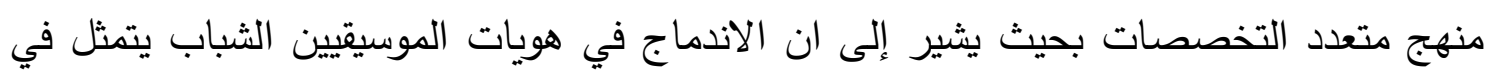

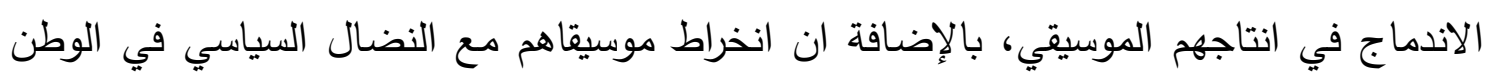
يعكس مدى ارتباط الثباب العربي في المهجر بهويتهم الوطنية.

\section{Bibliography}

* مدرس مساعد في قسم اللغة الإنجليزية، كلية الآداب، جامعة القاهرة. 
47Soul. "Q\&A Live from YouTube Space Dubai.” Interview with Azza Za'rour, July 11, 2019.

https://www.youtube.com/watch?v=YvLSyoRF-kY\&t=171s.

47Soul. "Shamstepping Across Borders." SceneNoise, June 3, 2018.

https://www.youtube.com/watch?v=meU_TAoaz58.

47Soul. "Palestinian supergroup 47Soul stay true to their roots." The National, Aug. 17, 2016. https://www.thenationalnews.com/artsculture/palestinian-supergroup-47soul-stay-true-to-their-roots1.151053? videoId=5586140233001.

47Soul. "Reviving the Shami Folk Heritage." France 24 Arabic, May 6, 2016. https://www.youtube.com/watch?v=xYRhVCrk8DQ

Abu Kwaik, Tareq. "Traditional Arabic Street Music Gets Electronic."

BBC News, March 21, 2015. https://www.bbc.com/news/av/worldmiddle-east-31986705/traditional-arabic-street-music-gets-electronic Al-Hakim, Tawfiq. The Revolt of the Young: Essays by Tawfiq al-Hakim. Translated by Mona Radwan. New York: Syracuse University Press, 2015.

Ashcroft, Bill, Gareth Griffiths, and Helen Tiffin. Post-Colonial Studies: The Key Concepts. New York: Routledge, 2007.

Bhabha, Homi. "The Third Space." In Identity: Community, Culture, and Difference, edited by Jonathan Rutherford, 207-221. London: Lawrence and Wishart, 1990.

---. The Location of Culture. New York: Routledge Classics, 2004.

Belkind, Nili. "Music in Conflict: Palestine, Israel, and the Politics of Aesthetic Production." PhD. diss., Columbia University, 2014.

Frith, Simon. "Music and Identity." In Questions of Cultural Identity, edited by Stuart Hall and Paul Du Gay, 108-127. London: Sage Publications, 2003.

Hall, Stuart. "Cultural Identity and Diaspora." In Identity: Community, Culture, Difference. Edited by Jonathan Rutherford, 222-237. London: Lawrence \& Wishart, 1990.

Hammer, Juliane. Palestinians Born in Exile: Diaspora and the Search for a Homeland. Cairo: American University Press, 2005.

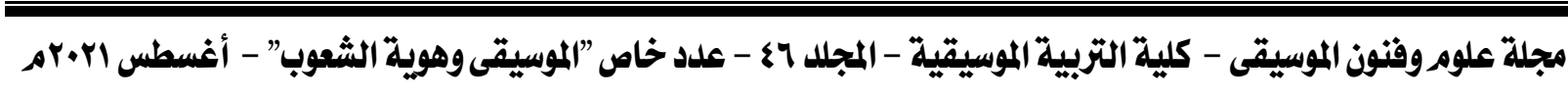


Herrera, Linda and Asef Bayat. Being Young and Muslim: New Cultural Politics in The Global South and North. New York: Oxford University Press, 2010.

Kadoda, Gada and Sondra Hale. "Contemporary Youth Movements and the Role of Social Media in Sudan." Canadian Journal of African Studies 49, no. 1 (2015): 215-236.

Maira, Sunaina. Jil Oslo: Palestinian Hip Hop, Youth Culture, and the Youth Movement. Washington: Tadween Publishing, 2013.

McDonald, David A. My Voice Is My Weapon: Music, Nationalism, and the Poetics of Palestinian Resistance. London: Duke University Press, 2013.

Nabil, Rowa. "The Young Sing Back: On Protest Songs and the Rise of an Alternative National-Popular Consciousness in the Arab World." Master's thesis, Cairo University, 2020.

Swedenburg, Ted. Memories of Revolt: The 1936-1939 Rebellion and the Palestinian National Past. Minneapolis: University of Minnesota Press, 1995.

Weiss, Sarah. "Permeable Boundaries: Hybridity, Music, and the Reception of Robert Wilson's "I La Galigo." Ethnomusicology 52, no. 2 (Spring/Summer 2008): 203-238.

Wong, Chuen-Fung. "Conflicts, Occupation, and Music-Making in Palestine." Macalester International 23 (2009): 267-284.

Youssef, Ayman. "Ayman Mao: The Voice of the Revolution in Sudan." $B B C$, May 15, 2019. https://www.bbc.com/arabic/media-48283255 


\section{Discography}

47Soul. "Intro to Shamstep." Track 1 on Shamstep, Independent Records Ltd, 2015, compact disc.

47Soul. "Every Land." Track 5 on Shamstep, Independent Records Ltd, 2015, compact disc.

Nas Jota. "b-Sotak" [with Your Voice/Vote]. Nas Jota Records, 2010. Electronic.

Nas Jota. "La lil Diktatoreya" [No to Dictatorship]. Nas Jota Records, 2012. Electronic. 